\title{
Diet, Epidemiological Factors and Cognitive Impairment: A Cross-Sectional Study in the Elderly Population
}

\begin{abstract}
Vivian Francielle França ${ }^{1}$, Thairine Azzolini $^{2}$, Ediane Pissaia $^{2}$, Durcelina Schiavoni Bortoloti $^{3}$, Taise Signorini ${ }^{4}$, Lediana Dalla Costa ${ }^{5}$, Marília Moraes Queiroz Souza ${ }^{6}$, Francislaine Aparecida dos Reis Lívero ${ }^{6}$, Evellyn Claudia Wietzikoski Lovato ${ }^{7^{*}}$

${ }^{1}$ Multidisciplinary Institute in Health, Federal University of Bahia, Bahia, Brazil ${ }^{2}$ Laboratory of Nutrition, Paranaense University, Francisco Beltrão, Brazil ${ }^{3}$ Laboratory of Physical Education, Paranaense University, Francisco Beltrão, Brazil ${ }^{4}$ Laboratory of Psychology, Paranaense University, Francisco Beltrão, Brazil ${ }^{5}$ Laboratory of Nursing, Paranaense University, Francisco Beltrão, Brazil ${ }^{6}$ Laboratory of Preclinical Research of Natural Products, Post Graduate Program in Medicinal Plants and Phytotherapics in Basic Attention and Graduate Program in Animal Science with Emphasis on Bioactives Products, Paranaense University, Umuarama, Brazil ${ }^{7}$ Laboratory of Neurosciences, Post Graduate Program in Medicinal Plants and Phytotherapics in Basic Attention, Paranaense University, Umuarama, Brazil
\end{abstract}

ABSTRACT

Purpose Population aging is one of the great achievements of humanity. However, with aging, the incidence of chronic diseases and those related to cognition deficits increase. In this way, strategies aimed at preventing or delaying cognitive deficit are extremely necessary. Thus, this study investigates the relationship between cognitive deficits, schooling and eating habits in a Brazilian elderly population. Methods The dietary habits of 400 older adults were investigated through structured questionnaires. Unhealthy eating habits such as low consumption of fruits, vegetables and beans, consumption of fatty meats and whole milk, adjusted for other variables, were evaluated. Cognitive function was assessed by the Mini Mental State Examination (MMSE). Data were analyzed by Chi-square test and binary logistic regression. Results There was cognitive deficit prevalence of $17.7 \%$ in the study population, which increases with age progression. The low frequency of vegetable consumption increased the risk of cognitive deficit in the crude analysis by $47.6 \%$ and increased these odds by $44.1 \%$ after the final adjustment. Low educational level was also associated with cognitive deficit of individuals (28.25\%). Conclusion Educational level and vegetable consumption in adult life and in later adulthood improve cognition.

Keywords Aging, cognitive, diet, fruits, schooling, vegetable.

\footnotetext{
* Author for correspondence: evellyn@ prof.unipar.br
} 


\section{INTRODUCTION}

Population is aging, and this phenomenon occurs in an accelerated manner due to improvements in quality of life, schooling, and greater coverage in population-based health services ${ }^{1}$. World projections for 2025 indicate a $223 \%$ increase in the number of older adults, which will total 1.2 billion people over 60 years, of which approximately 30 million will be Brazilians ${ }^{2}$. However, this increase in longevity has been accompanied by a high incidence of aging-related neurodegenerative diseases. Even if aging occurs in a healthy way, it is possible to observe changes in the brain structures that may result in cognitive deficits and dementia ${ }^{3,4}$. Currently, dementia is one of the most important causes of morbidity and mortality among older adults and represents a significant public health problem due to the long and complex nature of functional, emotional and social consequences for both patients and their families ${ }^{5}$. Thus, one of the great challenges of this century is to prevent, treat and reverse diseases related to age advancement, such as those characterized by cognitive dysfunctions.

The early recognition of cognitive changes in this population is important because it allows proposing care aimed at the prevention of cognitive deficit and dementia ${ }^{6}$. Furthermore, it is important to understand that in addition to age progression ${ }^{7}$, lower educational level and income ${ }^{8}$, sedentary lifestyle ${ }^{9}$, presence of chronic diseases, smoking, excessive alcohol consumption and inadequate dietary habits ${ }^{11}$ may negatively influence cognitive function.

In fact, five or more servings of fruits and vegetables consumed daily, and increased fish consumption may positively impact the cognitive function of older adults ${ }^{11,12}$. This occurs because fruits and vegetables are sources of vitamins C, E, carotenoids and flavonoids, which exert antioxidant function and reduce oxidative processes in brain structures that promote cognitive deficit ${ }^{13}$. On the other hand, the consumption of saturated fat present in fatty meats and whole milk products are negatively associated with cognitive deficit ${ }^{14}$. Beans, a good source of zinc, may promote positive effects on cognition due to their participation in protein synthesis and antioxidant capacity ${ }^{15,16}$.

Thus, through an explanatory logistic regression model, this research investigated the association between epidemiological variables, dietary habits and cognitive function in a Brazilian elderly population to identify factors that may be used to prevent or attenuate cognitive decline.

\section{MATERIAL AND METHODS}

\section{Population And Sample}

A cross-sectional study conducted with older adults ( $\geq 60$ years old) of both sexes, assisted by Community Health Agents (CHA) in nine Family Health Strategy (FHS) units in the city of Francisco Beltrão, Paraná was conducted. According to census carried out by IBGE $(2010)^{3}$, the population with 60 years or more in this municipality is 8,264 individuals, representing $10.4 \%$ of the city population. For the sample calculation, prevalence of $19 \%$ (cognitive deficit), accuracy of $2.5 \%$, significance level of $5 \%$ and reliability of $99 \%$ were considered. The study sample was composed of 400 older adults. The sampling process was random simple. Data collection was performed by undergraduate nutrition students, duly trained for this purpose. Collection was carried out in households from July to November, 2013, in morning and afternoon sessions, along with CHA visits that indicated the residence of participants in each unit. 
As inclusion criteria, participants should be able to hear and understand instructions and present no cognitive disorders and/or advanced mental illnesses that avoided understanding and performing the procedures for the cognitive function screening, reported by family members or CHA. The study was approved by the Research Ethics Committee Involving Human Beings of the Paranaense University (CAAE 07581912.1.0000.0109). Participants gave their free and informed consent in writing to participate in the research.

\section{Cognition Evaluation}

Cognitive function (dependent variable) was investigated by the Mini Mental State Examination (MMSE) screening instrument validated for older adults in Brazil ${ }^{17}$. Cutoff points of 19/20 were considered for participants without any schooling level and $23 / 24$ for those with some schooling level ${ }^{18}$. Responses were categorized as absence of cognitive deficit and possible cognitive deficit.

\section{Independent Variables Evaluation}

Information on "unhealthy eating habits" was included as independent variables of the study. Insufficient consumption of fruits, vegetables, beans, reports of consumption of red meat with apparent fat, chicken with skin and whole milk were considered indicators of unhealthy eating habits.

Weekly consumption of fruits, vegetables and beans was investigated by the questions: "On how many days of the week do you usually eat fruits?", "On how many days of the week do you usually eat vegetables or cooked vegetables?" and "On how many days of the week do you usually eat beans?". Consumption of fruits, vegetables and beans consumption was considered adequate ( $\geq 5$ times per week) or inadequate ( $\leq 4$ times per week).

The consumption of meat with apparent fat was investigated by the questions: "When you consume red meat with visible fat do you usually eat the fat?" (No, I either remove excess visible fat or I do not eat red meat with visible fat; Yes, I eat with fat). For the analysis, the consumption of meat without visible fat was considered adequate. "When do you consume chicken with skin, do you usually eat with the skin?" (No, I always remove the skin or do not eat chicken with the skin; Yes, I eat chicken with the skin). The consumption of chicken without the skin was considered adequate.

"When you drink milk, what kind of milk do you usually drink?" (Skimmed or semiskimmed; whole milk, does not apply). For the analysis, the consumption of skimmed or semi-skimmed milk was considered adequate.

\section{Adjustment Variables}

For the analysis of association, adjustment was made for the following variables: sex (male, female); age (60 to 69 years, 70 to 79 years, 80 years or more); educational level (any degree of education, illiterate); income (up to 1 minimum wage, 2 to 3 minimum wages, more than 3 minimum wages); smoking (non-smoking); ingestion of alcoholic beverages (yes, no); presence or absence of diseases, as investigated: "Some doctor or nurse has already told you that you have systemic arterial hypertension (SAH), diabetes mellitus (DM), cardiovascular disease (CVD), and/or dyslipidemia?" or "Do you take medicine for SAH, DM, DCV and/or dyslipidemia?" (yes, no); and body mass $(\mathrm{kg})$, height $(\mathrm{m})$ and waist circumference measurements $(\mathrm{cm})$. Body mass and height were measured using technique standardized by Frisancho ${ }^{19}$. In bedridden or compromised individuals, it was estimated using the Chumlea equation ${ }^{20}$ and body 
mass estimated by the Chumlea equation ${ }^{21}$. Body mass index (BMI; body mass/stature ${ }^{2}$ ) was classified by cutoff points proposed by the Food and Nutrition Surveillance System (SISVAN) ${ }^{22}$. Cutoff points were underweight (BMI $<22.0$ $\mathrm{kg} / \mathrm{m}^{2}$ ), normal weight (BMI $\geq 22.0$ and $<27.0 \mathrm{~kg} / \mathrm{m}^{2}$ ) and overweight (BMI $\geq 27.0$ $\left.\mathrm{kg} / \mathrm{m}^{2}\right)$.

\section{STATISTICAL ANALYSES}

The chi-square test was used to verify associations among variables. Binary logistic regression estimated the risk odds ratio (OR) of variables unhealthy eating habits involved in cognitive function. Crude and adjusted analyses were performed for variables that entered the model from the Wald test ( $p$-value $<0.20)$. Significance level was $\mathrm{p}<0.05$, with $95 \%$ confidence interval (CI). SPSS ${ }^{\circledR}$ software version 17.0 was used for all analyses.

\section{RESULTS}

A total of 400 older adults aged 60 years or more of both sexes participated in the study. Of these, 204 aged between 60 and 69 years, 133 between 70 and 79 years and 63 aged 80 years or more. Most of the sample $(72 \%, n=288)$ consisted of women. The prevalence increases with age progression, being estimated in $10.8 \%$ for participants aged 60 - 69 years and $41 \%$ for those with 80 years or older. Low educational level was associated with cognitive deficit: 113 individuals were illiterate (28.25\%), 269 had 1 to 4 schooling years $(67.25 \%)$ and 18 had 5 years or more schooling years $(4.5 \%)$. The estimated prevalence of possible cognitive deficit was $17.7 \%(n=71)$. Sex, income, smoking, alcohol consumption, chronic diseases and BMI were not associated with cognitive deficit (Table 1).

Table 1. Epidemiological factors of the study population related to cognitive function.

\begin{tabular}{|c|c|c|c|c|c|}
\hline \multirow[t]{2}{*}{ Variables } & \multirow{2}{*}{\multicolumn{2}{|c|}{$\begin{array}{c}\text { Absence of cognitive } \\
\text { deficit } \\
\%\end{array}$}} & \multicolumn{2}{|c|}{$\begin{array}{c}\text { Probable cognitive } \\
\text { deficit }\end{array}$} & \multirow[t]{2}{*}{ p-value* } \\
\hline & & & $\mathbf{n}$ & $\%$ & \\
\hline \multicolumn{6}{|l|}{ Sex } \\
\hline Men & 93 & 83.0 & 19 & 17.0 & 0.798 \\
\hline Women & 236 & 81.9 & 52 & 18.1 & \\
\hline \multicolumn{6}{|l|}{ Age (years) } \\
\hline $60-69$ & 182 & 89.2 & 22 & 10.8 & $<0.001 *$ \\
\hline $70-79$ & 109 & 82.0 & 24 & 18.0 & \\
\hline$\geq 80$ & 37 & 59.0 & 26 & 41.0 & \\
\hline \multicolumn{6}{|c|}{$\overline{\text { Schooling (years) }}$} \\
\hline Illiterate & 84 & 74.3 & 29 & 25.7 & $0.008 *$ \\
\hline $1-4$ & 227 & 84.4 & 42 & 15.6 & \\
\hline$\geq 5$ & 18 & 100 & - & - & \\
\hline \multicolumn{6}{|c|}{ Income (minimum wage) } \\
\hline$\leq 1$ & 178 & 79.1 & 47 & 20.9 & 0.092 \\
\hline $2-3$ & 131 & 85.1 & 23 & 14.9 & \\
\hline$\geq 3$ & 20 & 95.2 & 1 & 4.8 & \\
\hline \multicolumn{6}{|c|}{ Fruit consumption (times per week) } \\
\hline$\geq 5$ & 188 & 85.5 & 32 & 14.5 & 0.064 \\
\hline$\leq 4$ & 141 & 78.3 & 39 & 21.7 & \\
\hline \multicolumn{6}{|c|}{ Vegetables consumption (times per week) } \\
\hline$\geq 5$ & 234 & 85.4 & 40 & 14.6 & 0.015* \\
\hline$\leq 4$ & 95 & 75.4 & 31 & 24.6 & \\
\hline \multicolumn{6}{|c|}{ Beans consumption (times per week) } \\
\hline$\geq 5$ & 203 & 85.3 & 35 & 14.7 & 0.053 \\
\hline$\leq 4$ & 126 & 78.8 & 36 & 22.2 & \\
\hline \multicolumn{6}{|c|}{ Red meat with fat consumption } \\
\hline No & 217 & 82.2 & 47 & 17.8 & 0.926 \\
\hline
\end{tabular}




\begin{tabular}{|c|c|c|c|c|c|}
\hline Yes & 109 & 82.6 & 23 & 17.4 & \\
\hline \multicolumn{6}{|c|}{ Chicken with skin consumption } \\
\hline No & 244 & 82.7 & 51 & 17.3 & \multirow{2}{*}{$\begin{array}{l}0.627 \\
\text { Cont. }\end{array}$} \\
\hline Yes & 83 & 80.6 & 20 & 19.4 & \\
\hline \multicolumn{6}{|l|}{ Type of milk consumed } \\
\hline Skimmed or semi-skimmed & 44 & 89.8 & 5 & 10.2 & \multirow[t]{2}{*}{0.121} \\
\hline Whole milk & 257 & 80.8 & 61 & 19.2 & \\
\hline \multicolumn{6}{|l|}{ Smoking } \\
\hline No & 216 & 83.7 & 42 & 16.3 & \multirow[t]{2}{*}{0.299} \\
\hline Yes & 113 & 79.6 & 29 & 20.4 & \\
\hline \multicolumn{6}{|c|}{ Alcoholic beverages consumption } \\
\hline No & 305 & 82.7 & 64 & 17.3 & \multirow[t]{2}{*}{0.464} \\
\hline Yes & 24 & 77.4 & 7 & 22.6 & \\
\hline \multicolumn{6}{|l|}{ Hypertension } \\
\hline No & 90 & 85.7 & 15 & 14.3 & \multirow[t]{2}{*}{0.279} \\
\hline Yes & 239 & 81.0 & 56 & 19.0 & \\
\hline \multicolumn{6}{|l|}{ Cardiovascular disease } \\
\hline No & 266 & 81.3 & 61 & 18.7 & \multirow[t]{2}{*}{0.316} \\
\hline Yes & 63 & 86.3 & 10 & 13.7 & \\
\hline \multicolumn{6}{|l|}{ Diabetes mellitus } \\
\hline No & 258 & 81.9 & 57 & 18.1 & \multirow[t]{2}{*}{0.728} \\
\hline Yes & 71 & 83.5 & 14 & 16.5 & \\
\hline \multicolumn{6}{|l|}{ Dyslipidemia } \\
\hline No & 252 & 82.1 & 55 & 17.9 & \multirow[t]{2}{*}{0.875} \\
\hline Yes & 77 & 82.8 & 16 & 17.2 & \\
\hline \multicolumn{6}{|l|}{ Body mass index } \\
\hline Underweight & 90 & 22.6 & 25 & 6.3 & \multirow[t]{3}{*}{0.103} \\
\hline Normal weight & 41 & 10.3 & 13 & 3.3 & \\
\hline Overweight & 197 & 49.4 & 33 & 8.3 & \\
\hline
\end{tabular}

* Chi-square test $p<0.05$.

Participants with low consumption of vegetables $(\leq 4$ times a week) were $47.6 \%$ more likely of being at risk for cognitive deficit in the crude analysis (OR: 0.524; CI: 0.310; 0.877). After adjusting for age, sex, schooling and income, the chances of risk for cognitive deficit increased 44.1\% (OR: 0.559; CI: 0.317; 0.986). Consumption of fruits, beans, whole milk, red meat with visible fat and chicken with the skin showed no risk or protection for cognitive function (Table 2).

Table 2. Estimated coefficients of the logistic regression model for cognitive function and dietary habits of participants.

\begin{tabular}{|c|c|c|c|c|c|c|}
\hline \multirow[t]{2}{*}{ Variables } & \multicolumn{3}{|c|}{ Crude analyses } & \multicolumn{3}{|c|}{ Adjusted analyses } \\
\hline & OR & CI 95\% & $\mathbf{P}$ & OR & CI 95\% & $\mathbf{P}$ \\
\hline \multicolumn{7}{|c|}{ Vegetables (times per week) } \\
\hline$\geq 5$ & & 1 & & & 1 & \\
\hline$\leq 4$ & 0.524 & $0.310 ; 0.887$ & 0.016 & 0.559 & $0.317 ; 0.986$ & 0.045 \\
\hline \multicolumn{7}{|c|}{ Fruits (times per week) } \\
\hline$\geq 5$ & & 1 & & & 1 & \\
\hline$\leq 4$ & 0.615 & $0.367 ; 1.031$ & 0.065 & 0.627 & $0.357 ; 1.100$ & 0.104 \\
\hline \multicolumn{7}{|c|}{ Beans (times per week) } \\
\hline$\geq 5$ & & 1 & & & 1 & \\
\hline$\leq 4$ & 0.603 & $0.360 ; 1.011$ & 0.055 & 0.650 & $0.373 ; 1.133$ & 0.128 \\
\hline \multicolumn{7}{|c|}{ Red meat with fat } \\
\hline No & & 1 & & & 1 & \\
\hline Yes & 1.026 & $0.593 ; 1.778$ & 0.926 & 1.053 & $0.568 ; 1.952$ & 0.869 \\
\hline \multicolumn{7}{|c|}{ Chicken with skin } \\
\hline No & & 1 & & & 1 & \\
\hline Yes & 0.867 & $0.489 ; 1.540$ & 0.627 & 0.952 & $0.505 ; 1.793$ & 0.878 \\
\hline \multicolumn{7}{|l|}{ Milk } \\
\hline Skimmed & & 1 & & & 1 & \\
\hline Whole milk & 0.479 & $0.189 ; 1.258$ & 0.135 & 0.544 & $0.199 ; 1.487$ & 0.998 \\
\hline
\end{tabular}


Binary Logistic Regression: Odds Ratio (OR). Significance level of 5\% ( $<$ 0.005). Analysis adjusted for age, sex, schooling and income. For adjustment, $p$-value $<0.20$ was considered in the Wald test.

\section{DISCUSSION}

The projection of the population pyramid indicates an increase in longevity, frailty, development of chronic degenerative diseases, autonomy impairment, fragile family structure and deficits in several aspects related to quality of life, which are objects of concern and studies in Brazil and other countries ${ }^{23}$. The life-style knowledge that elderly subjects had throughout their lives is an important tool to determine which factors are closely related to the processes of loss of cognition and to point out strategies that can be used to prevent this process. In the elderly population investigated in this research, two factors are directly related to loss of cognition: low schooling and low consumption of vegetables ( $\leq 4$ times per week).

Age progression is the main determining factor the loss of cognition in the elderly ${ }^{24,25}$. It occurs because aging is conditioned by changes in brain structures ${ }^{26}$. Higher schooling may be related to better cognitive function, since it makes the brain more resilient and flexible against the effects of diseases or common alterations of aging ${ }^{24}$. In addition, low schooling can be related to occupation, income, health and lifestyle over the years ${ }^{27}$. In fact, in this research, advanced age, illiteracy or low educational level were associated with worse cognitive function. However, income was not related to cognitive decline.

Other factor considered as a longevity limitation is the oxidative stress, a redox status disruption, associated to several aging-related diseases, such as Alzheimer and Parkinson neurodegenerative diseases ${ }^{28,29}$. Brain tissue contains high levels of polyunsaturated fatty acids and appears to have less antioxidant protection, being more susceptible to damage from oxidative stress than other tissues ${ }^{29}$. Fruits and vegetables present components that can promote benefits to cognitive function by exerting antioxidant activity, providing protection against oxidative stress in the brain ${ }^{30,31}$. These foods are good sources of vitamins B6 and folate. It is worth mentioning that these components participate in reactions that allow the control the excess of serum homocysteine, being a protective factor to cognition ${ }^{32}$. In addition, vegetables contain high amounts of vitamin $\mathrm{E}$, and when consumed with additional fats, they improve the absorption of this vitamin, carotenoids and flavonoids ${ }^{13}$. These factors may explain why older adults who consumed more than 5 servings of vegetables per week presented better cognitive function in this investigation.

The same response pattern was found in a Chinese study with 6,911 illiterate older adults, who found that the higher consumption of vegetables resulted in lower chances for cognitive deficit assessed by $\mathrm{MMSE}^{34}$. Another Chinese study found that lower intakes of vegetables were associated with cognitive impairment in individuals aged 90 years or older ${ }^{34}$. However, Brazilian surveys evaluating food consumption patterns and epidemiological data are widely varied. A survey conducted with 1,558 older adults from Minas Gerais revealed that individuals with lower frequency of fruit and vegetable consumption ( $<5$ times per week) were 1.94 times more likely of having lower MMSE scores ${ }^{35}$. Another study conducted in Santa Catarina, evaluated 1,197 individuals aged over 60 years. For women $(n=778)$, the results showed higher mean MEEM scores according to the increase in the daily frequency of fruit and vegetable (> 4 servings/day) consumption. The same was not observed in men ${ }^{11}$. This variation of results can be explained by the different cutoff points adopted in studies and by the wide economic and sociocultural diversity of the country, reflected by different schooling levels and food consumption. 
These data establish relevant points regarding the attention that should be given to older adults in their inclusion in educational activities that can contribute to their formation, adequate reading and writing, activities that will result in greater autonomy in their daily activities, which require mastering certain skills that may collaborate to improve cognition function. In the same sense, healthier diet that includes the consumption of vegetables at least 5 times per week should be encouraged. This simple and inexpensive measure has significant effects on the cognitive function and quality of life of elderly individuals. In the case of an older adult with already established cognitive loss, these prevention measurements are never too late, which will slow down the progression of the disease.

Aging stems from normal development and involves structural, functional, and biochemical neurobiological changes. These alterations influence the organism, and environmental and socio-cultural factors (quality of life and lifestyle, diet, physical inactivity and physical activity) are closely linked to both healthy and pathological aging. However, in the presence of cognitive and other dysfunctions, diagnosis and early intervention may provide a better quality of life for patients and their families ${ }^{36}$. Aging is also a social construct that depends on the context in which individuals are inserted, experiences and opportunities that they have had. From the biological point of view, it is a unique phenomenon, and from the social point of view, it is a plurality of phenomena ${ }^{37}$. So, interventions that improve cognition in the elderly are extremely necessary to provide better quality of life for these individuals.

\section{CONCLUSION}

High weekly consumption of vegetables and schooling are protective factors of cognition in the elderly. The consumption of vegetables and educational activities are simple and inexpensive measures that should be adopted during adult life for the promotion of healthy aging and protection of cognitive health.

\section{ACKNOWLEDGEMENTS}

Our immense gratitude to Secretaria Municipal de Saúde of Francisco Beltrão, to professionals of Estratégia Saúde da Família for the inestimable help in data collection and to Paranaense University for the financial support of this research.

\section{CONFLICT OF INTEREST}

The author declares no conflict of interest in this research.

\section{REFERENCES}

1. Veras R. Envelhecimento populacional contemporâneo: demandas, desafios e inovações. Rev Saúde Pública. 2009; 43: 548-554.

2. Instituto Brasileiro de Geografia e Estatística (IBGE). Projeção da População do Brasil por sexo e idade: 2000 - 2060. Available on: http://www.ibge.gov.br/home/estatistica/populacao/projecao_da_populacao/2013/default_tab.s htm. Access: May $31^{\text {th }}, 2017$.

3. Instituto Brasileiro de Geografia e Estatística - IBGE. Projeção da população no município de Francisco Beltrão. Brasília: IBGE; 2010.

4. Lupton MK, Strike L Hansell NK, Wen W, Mather KA, Armstrong NJ. The effect of increased genetic risk for Alzheimer's disease on hippocampal and amygdala volume. Neurobiology of Aging. 2016; 40: 68-77. doi: 10.1016/j.neurobiolaging.2015.12.023 
5. Machado JC, Ribeiro RCL, Catta RMM, Leal PFG. Cognitive decline of aged and its association with epidemiological factors in the city of Viçosa, Minas Gerais. Rev Bras Geriatr Geronto.l 2011; 14: 109-121. doi: 10.1590/S1809-98232011000100012

6. Valcarenghi RV, Santos SSC, Barlem ELD, Pelzer MT, Gomes GC, Lange C. Alterações na funcionalidade/cognição e depressão em idosos institucionalizados que sofreram quedas. Acta Paul Enferm. 2011; 24: 828-833. doi: 10.1590/S0103-21002011000600017

7. Andrade CD, Corona LP, Lebrão ML, Duarte YAO. Life expectancy with and without cognitive impairment among Brazilian older adults. Archives of Gerontology and Geriatrics. 2014; 58: 219-225. doi: 10.1016/j.archger.2013.10.007

8. Bottino CMC, Azevedo D, Tatsch M, Hototian SR, Moscoso MA, Folquitto J. Estimate of dementia prevalence in a community in São Paulo, Brazil. Dementia Geriatric Cognitive Disorders. 2008; 26: 291-299. doi: 10.1159/000161053

9. Franco-Martin M, Parra-Vidales E, Gonzales-Palau F, Bernadete-Navarro M, Solis A. The influence of physical exercise in the prevention of cognitive deterioration in the elderly: a systematic review. Revista de Neurologia. 2013; 56: 545-54.

10. Eshkoor SA, Hamid TA, Mun CY, Kyun C. Mild cognitive impairment and its management in older people. Clinical Interventions in Aging. 2015; 10: 687-693. doi: 10.2147/CIA.S73922

11. França VF, Barbosa AR, D’Orsi E. Cognition and Indicators of Dietary Habits in Older Adults from Southern Brazil. Plos One. 2016; 11: e0147820. doi: 10.1371/journal.pone.0147820

12. Berti V, Murray J, Davies M, Spector N, Tsui WH, Li Y. Nutrient patterns and brain biomarkers of Alzheimer's disease in cognitively normal individuals. J Nutr Health Aging. 2015; 4: 413-423. doi: 10.1007/s12603-014-0534-0

13. Morris MC, Evans DA, Tangney CC, Bienias JL, Wilson RS. Associations of vegetable and fruit consumption with age-related cognitive change. Neurology. 2006; 67: 1370-1376. doi: 10.1212/01.wnl.0000240224.38978.d8

14. Torres SJ, Lautenschlager NT, Wattanapenpaiboon N, Greenop KR, Beer C, Flicker L. Dietary Patterns Are Associated with Cognition among Older People with Mild Cognitive Impairment. Nutrients. 2012; 4, 1542-1551. doi: 10.3390/nu4111542

15. Nuttall JR, Oteiza PI. Zinc and the aging brain. Genes Nutr. 2014; 9: 379.doi: 10.1007/s12263-013-0379-x

16. Gómez-Pinilla F. Brain foods: the effects of nutrients on brain function. Nat Rev Neurosci. 2008; 9: 568-578. doi:10.1038/nrn2421

17. Bertolucci PHF, Brucki SMD, Campacci SR, Juliano Y. O Mini-exame do estado mental em uma população geral: impacto da escolaridade. Arquivos de Neuro-Psiquiatria. 1994; 52:17.

18. Scazufca M, Almeida OP, Vallada HP, Tasse WA, Menezes PR. Limitations of the MiniMental State Examination for screening dementia in a community with low socioeconomic status. Eur Arch Psychiatry Clin Neurosci. 2009; 259: 8-15. doi: 10.1007/s00406-008-0827-6

19. Frisancho AR. New standards of weight and body composition by frame size and height for assessment of nutritional status of adults and the elderly. Am J Clin Nutr. 1984; 40: 808-19.

20. Chumlea WC, Guo S. Equations for predicting stature in white and black elderly individuals. J Gerontol. 1992; 47: 197-203.

21. Chumlea WC, Guo S, Roche AF, Steinbaugh ML. Prediction of boby weight for the nonambulatoru elderly from anthropometry. J Am Diet Assoc. 1988; 88: 564-568.

22. Brasil. Ministério da Saúde. Vigilância alimentar e nutricional - Sisvan: orientações básicas para a coleta, processamento, análise de dados e informação em serviços de saúde Brasília: Ministério da Saúde, 2004.

23. Domiciano BR, Braga DKA, Silva PN, Vasconcelos TB, Macena RHM. Education, age, and cognitive impairment of elderly residents in long-term institutions. Rev Neurocienc. 2014; 22: 330-336. doi: 10.4181/RNC.2014.22.03.971.7p

24. Coelho FGM, Vital TM, Novais IP, Costa GA, Stella F, Santos-Galduroz RF. Desempenho cognitivo em diferentes níveis de escolaridade de adultos e idosos ativos. Rev Bras Geriatr Gerontol. 2012; 15: 7-15. doi: 10.1590/S1809-98232012000100002

25. Soares LM, Cachioni M, Falcão DV, et al. Determinants of cognitive performance among community dwelling older adults in an impoverished sub-district of São Paulo in Brazil. 
Archives of Gerontology and Geriatrics. 2012; 54: 187-192. doi: 10.1016/j.archger.2011.11.014.

26. Wisse LE, Biessels GJ, Heringa SM, Kuijf HJ, Koek DH, Luijten PR. Hippocampal subfield volumes at 7T in early Alzheimer's disease and normal aging. Neurobiol Aging. 2014; 35: 2039-2045. doi: 10.1016/j.neurobiolaging.2014.02.021

27. Maurer J. Education and Male-Female Differences in Later-Life Cognition: International Evidence From Latin America and the Caribbean. Demography. 2011; 48: 915-930. doi: 10.1007/s13524-011-0048-x.

28. Jones DP. Redefining Oxidative Stress. Antioxidants \& Redox Signaling. 2006; 8: 18651879.

29. Valko M, Leibfritz D, Moncol J, Cronin MTD, Mazur M, Telser J. Free radicals and antioxidants in normal physiological functions and human disease. The International Journal of Biochemistry \& Cell Biology. 2007; 39: 44-84. doi:10.1016/j.biocel.2006.07.001

30. Loef M, Walach H. Fruit, vegetables and prevention of cognitive decline or dementia: a systematic review of cohort studies. The Journal of Nutrition, Health \& Aging. 2012; 16: 626630.

31. Freeman LR, Granholm AC. Vascular changes in rat hippocampus following a high saturated fat and cholesterol diet. Journal of Cerebral Blood Flow \& Metabolism. 2012; 32: 643-653. doi: 10.1038/jcbfm.2011.168.

32. Bonetti F, Brombo G, Magon S, Zuliani G. Cognitive status according to homocysteine an B-group vitamin in elderly adults. The American Geriatrics Society. 2015; 63: 158-1163. doi: $10.1111 /$ jgs.13431.

33. Chen X, Huang Y, Cheng HG. Lower intake of vegetables and legumes associated with cognitive decline among illiterate elderly chinese: a 3-year cohort study. J Nutr Health Aging. 2012; 16: 549-552.

34. Wang Z, Dong B, Zeng G, Li J, Wang W, Wang B. Is there an association between mild cognitive impairment and dietary pattern in Chinese elderly? Results from a cross-sectional population study. BMC Public Health. 2010; 10: 2-7. doi: 10.1186/1471-2458-10-595

35. Valle AE, Castro-Costa E, Firmo JOA, Uchoa E, Lima-Costa M. Estudo de base populacional dos fatores associados ao desempenho no Mini Exame do Estado Mental entre idosos: Projeto Bambuí. Cad Saúde Pública. 2009; 25: 918-926. doi: 10.1590/S0102311X2009000400023

36. Santos FH, Andrade VM, Bueno OFA. Aging: a multifactorial process. Psicol estud. 2009; 14: 3-10. doi.org/10.1590/S1413-73722009000100002

37. Martínez-Maldonado ML, Vivaldo-Martínez M, Mendonza-Núñes VM. Comprehensive Gerontological Development. Gerontol Geriatr Med. 2016; 2: 1-6. doi: $10.1177 / 2333721416667842$ 